\title{
Assessment of Students' Satisfaction of Facility Service Quality in Private Universities
}

\author{
Thi My Hanh Le', Van Ky Long Nguyen,"*, Tien Son Nguyen², Tran Hoang Oanh Le², \\ Thi Ngoc Mai Duong ${ }^{2}$
}

\begin{abstract}
${ }^{1}$ Faculty of Digital Economy and E-Commerce, Vietnam-Korea University of Information and Communication Technology, The University of Danang, Vietnam

${ }^{2}$ Faculty of Business, FPT University, Vietnam
\end{abstract}

Received February 9, 2021; Revised March 22, 2021; Accepted April 22, 2021

\section{Cite This Paper in the following Citation Styles}

(a): [1] Thi My Hanh Le, Van Ky Long Nguyen, Tien Son Nguyen, Tran Hoang Oanh Le, Thi Ngoc Mai Duong, "Assessment of Students' Satisfaction of Facility Service Quality in Private Universities," Universal Journal of Educational Research, Vol. 9, No. 5, pp. 974-983, 2021. DOI: 10.13189/ujer.2021.090510.

(b): Thi My Hanh Le, Van Ky Long Nguyen, Tien Son Nguyen, Tran Hoang Oanh Le, Thi Ngoc Mai Duong (2021). Assessment of Students' Satisfaction of Facility Service Quality in Private Universities. Universal Journal of Educational Research, 9(5), 974-983. DOI: 10.13189/ujer.2021.090510.

Copyright $\bigcirc 2021$ by authors, all rights reserved. Authors agree that this article remains permanently open access under the terms of the Creative Commons Attribution License 4.0 International License

\begin{abstract}
Through globalization, the demand for high-quality education is increasing significantly, leading to rising competition among universities and colleges for enhancing educational services and attracting more students to enroll. Meanwhile, students are always looking for and demanding the most proper environments to experience education and have the foundation to find a job after graduation. This need leads to the tendency that education becomes a service that benefits both private education enterprises and their potential customers. Nevertheless, the private institutions might not have the reputation and sponsorship from the government as public universities. Therefore, the importance of studying the determinants of student satisfaction with the quality of services provided is increasingly essential and required for private educational institutions. This research aims to propose a research model in calculating the level of student satisfaction with the facility service quality in private institutions. This study was conducted using a questionnaire to survey 221 students of the FPT University Da Nang campus in the Fall semester of 2020. This research attempts to examine the relationship between facility service quality and student satisfaction, along with investigating the key factors in the aspects of service quality that contribute significantly to student satisfaction. The findings of this study identify the factors and the impact degree of these factors on student satisfaction of facility service quality in private universities.
\end{abstract}

Keywords Educational Service, Facility, Private University, Satisfaction, Service Quality

\section{Introduction}

In the trend of globalization, higher education has increasingly become a kind of service, which is directly related to the educational training process, and to provide other services in the school. With an ever-growing assortment of educational options, students seek institutions that will provide them with a unique educational experience that they will treasure for a lifetime, along with preparing for a successful career and gainful employment. By 2025, the projected global demand for higher education could reach 263 million students, which is an increase from a little less than 100 million students in 2000 [1]. This need leads to more and more widely established private educational institutions, making the most of human resources useful for the national economy. Education is no longer a non-profit service but becomes a service that benefits both private education enterprises and their potential customers.

Public universities have existed, developed, and built their reputation for a long time, meanwhile, private schools are the kind of university which is quite new to everyone 
and established significantly because of the increasing educational needs. However, private institutions do not have the reputation and sponsorship from the government as public academies, so they have to build brands, raise capital from investors, seek and convince students to enroll for studying. Institutional budgets are developed based upon projected enrolments; it is becoming crucial for private institutions to retain the students they recruit. Therefore, the importance of researching the determinants of student satisfaction with the quality of services provided is increasingly essential and required for private educational institutions to clearly define the competition in educational services [2]. In this view, to attract students, one proposal for private universities needs to improve the training quality, especially regularly improve and renew facility service quality to create lasting engagement with students and effectiveness in the provision of services commensurate with the expenses that students pay. Student satisfaction and academic performance have been the main focus of both scholars and policymakers in the competitive studying environment [3].

FPT University is one of the leading private universities in Vietnam training and applying for international standard educational programs. In Vietnam, in 2012, FPT University was the first university to be recognized as Three Stars according to QS Stars international standards of universities around the world [4]. In 2018, FPT Education became Vietnam's only educational organization to get two Brand Laureate awards, won the Premier Corporate Brands in Education Excellence, and got Best Brands in Education Tertiary [5]. With these award categories, FPT Education in general and FPT University, in particular, have affirmed the prestige, influence level, and training quality of the educational brand to domestic and international customers. Currently, the university is continuously expanding its training system, which results in a rapid increase in the number of students over the years. The base of Danang has been built and put into operation in 2019 [6], which has provided modern and advanced facilities and meet the demand for an enormous number of students studying at FPT University. Therefore, it is plausible to prefer FPT University as the representative for a private higher education institution, along with the student satisfaction research model that authors are working on, accordantly with the evaluation standards for other private educational institutions. Competitive pressure with other universities is therefore inevitable. To succeed in the quality race with other universities, one of the essential strategies is to enhance student satisfaction with the quality of service provided.

Since few articles are surveying the quality of facilities in private universities, especially in FPT University which has stable training and investment funding, this research will then emphasize the facility service quality. This study, firstly, aims to provide raw data, which was surveyed from students, to estimate their satisfaction with facility service quality. Secondly, this study seeks to explore aspects of service quality and calculate the level of satisfaction among students of private institutions. Accordingly, the authors can examine the research model with 5 factors that can significantly affect the student's satisfaction level in service quality, namely tangibles, reliability, responsiveness, assurance, and empathy. Besides, this study will provide outcomes and suggest several recommendations for private institutions in higher education to enhance their performance and operation. This paper also provides universities a tool to develop their competitive advantage in this highly aggressive competition, not only among the private entities but also the other public schools that already have extraordinary status in the education market.

The remaining structure of the paper continues with the theoretical background, the proposed framework, and materials and methods. Then the results are presented, followed by an in-depth discussion of results and observations. Based on the discussion, the last section of the paper is the conclusion with a summary and relevant contributions.

\section{Theoretical Background and Research Framework}

\subsection{The Relationship between Customer Satisfaction and Service Quality}

Customer satisfaction can be a multi-dimensional construct or a one-dimensional construct [7]. Satisfaction is a psychological state affected by two processes [8]:

(i). Expectation of the service before use

(ii). Perception of customers about the service after the experience.

Many studies have concluded that service quality leads to customer satisfaction $[9,10]$. Quality is the premise of satisfaction and is the main factor affecting satisfaction. Therefore, to improve customer satisfaction, suppliers must improve service quality. In other words, service quality and customer satisfaction have a close relationship with each other, in which service quality is what is created first and then determines customer satisfaction.

Based on the definitions above, we can state that: "The satisfaction of students with the quality of educational services is a comprehensive assessment of the educational activities that the school offers to students". The quality is not only generated by the service but also evaluates the process to meet the needs of students. In the field of education, the relationship between service quality and customer satisfaction has also been confirmed through many studies. Snipes and Thomson [11] investigated the factors influencing perceived quality in higher education of students by surveying students of 6 small and medium scale universities in 3 states of the United States. The 
results of regression analysis show that from 5 theoretical components of SERVQUAL 3 components are reliable enough: (1) empathy; (2) competence and reliability; (3) tangibles of the work environment.

Chua [12] has studied and evaluated the quality of higher education from many different perspectives: students, parents, lecturers, and seekers of labor resources. The results show that most of the components of the SERVQUAL model (including (1) tangibles, (2) reliability, (3) responsiveness, (4) assurance, and (5) empathy) are expected to be higher than what they received.

Tran [13] studied the factors affecting the satisfaction of students at Thai Nguyen University of Economics and Business Administration. The results of the theoretical model test show that 5 components impact student satisfaction on the quality of training. In which, the component that has the strongest impact on student satisfaction is the assurance of the staff and faculty, the second is reliability about the ability to fulfill the commitment, the third is the facilities, the fourth is the faculty, and ultimately is empathy.

Nguyen [14] surveyed student satisfaction with training activities at the University of Natural Sciences - National University of Ho Chi Minh City. The results of regression analysis show that student satisfaction depends on factors of decreasing influence as follows: firstly, the appropriateness and responsiveness of the training program, the qualification, and dedication of the faculty, the general skills students gain after the course, the level of responsiveness from the school, and the final is facilities for learning.

From the results of the above studies, service quality and customer satisfaction have a close relationship with each other, in which service quality (including 5 main factors: tangibles, reliability, responsiveness, assurance, and empathy) is an important factor affecting the satisfaction of customers. Thus, the higher the customer appreciation of the components of service quality, the higher their overall satisfaction with service quality and vice versa.

\subsection{Theoretical Background}

In 1985, Parasuraman et al. have identified 10 dimensions used by consumers in evaluating service quality [15]. In subsequent research, they found a high degree of correlation between several of these variables and consolidated them into 5 broad dimensions [16]:

(1) Tangibles: Appearance of physical facilities, equipment, and personnel, and communication materials [17].

Tangible elements in the educational service mentioned include facilities such as classrooms, libraries, dormitories. Tools or equipment are used to provide services such as electricity and water supply systems. A good training program but lack of facilities for learning, lack of practice rooms, the knowledge that students learn is only theoretical but not practical [18]. Therefore, the lack of physical facilities can negatively affect the teaching and learning activities of students at universities.

(2) Reliability: Ability to perform the promised service dependably and accurately [17].

It implies that the firm plays out the assistance right the primary time. It additionally means that the firm honors its promises [19]. Students' trust in the school is based on their ability to do exactly what is committed to academic conditions, the education service delivery policy, or the school's curriculum. This element is proven by many researchers in the study on training quality [20]. The fulfillment of what has been promised demonstrates the reputation of the school, especially in educational services, is of great interest, and the consumer who is willing to pay to choose a school is due to their belief in which the school has committed to such as good learning environment, high-quality training, ideal learning conditions [18].

(3) Responsiveness: Willingness to help customers and provide prompt service [17].

Parasuraman et al. highlighted that the responsiveness of willing employees involves telling customers exactly when things will be done, giving them undivided attention, promoting services, and responding to their requests. Responsiveness was ranked as the third dimension in SERVQUAL [21]. Dimension responsiveness according to Hardiyansyah a good consists of indicators of responding to each customer who wants to get service, officers perform services quickly, precisely, and carefully, and all customer complaints are responded to by officer [22]. This is also in line with Purwoastuti and Walyani who argue that the dimension responsiveness is the ability to help customers and provide services quickly or responsively, for example; the ability of university departments to student complaints, officers provide clear and easy to understand information, fast action when students need them [23].

(4) Assurance (credibility, security, competence, and courtesy): Knowledge and courtesy of employees and their ability to inspire trust and confidence [17].

The quality assurance in education services is directly related to the performance of the staff. The organizations arrange staff with competence, knowledge, and courtesy throughout the course of service delivery to learners. As the demand for quality education increases, there is an increasing demand for quality assurance for international universities where there is increased mobility of students, faculty, programs, and higher education institutions in the global network [24, 25]. Quality assurance can be a driver for organizations to accomplish excellence in higher education [26]. Students are at the core of higher education so investing time and money in the system, related to them 
can improve the assurance processes, bring student satisfaction [26].

(5) Empathy (easy access, good communications, and customer understanding): Caring, individualized attention the firm provides for its customer [17].

Empathy is the key driver to achieve a high-quality customer experience in service settings [27]. As a psycho-social concept, empathy is defined as the response to and the ability to feel what others are feeling [28]. Results show that both students and staff alike evaluate empathy as important in the co-created service experience [29]. The provision of individualized attention to students to positively influence student experience in learning was deemed important by both staff and students [30].

\subsection{Research Framework}

From the above literature discussion, the authors propose the research model with the following hypotheses:

$\mathbf{H 1}^{+}$: There is a positive relationship between the tangible dimension of service quality and student satisfaction.

H2 $^{+}$: There is a positive relationship between the reliability dimension of service quality and student satisfaction.

$\mathbf{H 3}^{\mathbf{*}}$ : There is a positive relationship between the responsiveness dimension of service quality and student satisfaction.

$\mathbf{H 4}^{+}$: There is a positive relationship between the empathy dimension of service quality and student satisfaction.

$\mathbf{H 5}^{+}$: There is a positive relationship between the assurance dimension of service quality and student satisfaction.

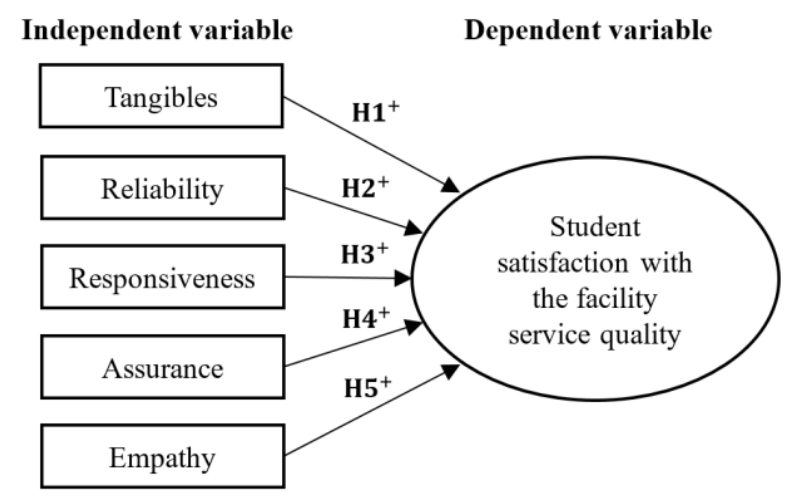

Figure 1. The research model of effects of service quality towards the student's satisfaction

Based on the study of service quality measurement theory, the study selects the SERVQUAL model to study the quality of providing facilities for students at private universities. The research model includes 21 observed variables, divided into 6 groups (including the dependent variable). Variables are measured on the 5-point Likert

scale: (1) Strong disagree; (2) Disagree; (3) Neutral; (4) Agree; (5) Strong agree.

\section{Materials and Methods}

\subsection{Data Collection}

According to Hair et al., the minimum sample is 100 and the best-observed ratio is 10:1 for applying EFA analysis [31]. The survey model in this study includes 6 representative variables, including five independent variables and one dependent variable. Because of 21 observed variables, therefore, the number of samples required is $21 * 10=210$ at least. To ensure a high-reliability level, the study investigated all K13, K14, and K15 students who have been using the facilities provided by FPT University Da Nang, and the results obtained 223 samples, of which two samples are invalid. This paper excluded K16 as they are new students and have not been using all services in the university for a long time.

Secondary data: To evaluate the quality of providing facilities for living and learning of students, this study used information from relevant departments in the university.

Primary data: The information about the service provided, the quality, and the student's satisfaction with the quality of services are gathered using the questionnaire surveys. Respondents were students of the second, third, and fourth years of study. The investigation of these students ensures that they are aware and have used the services provided in FPT University Da Nang.

\subsection{Methods of Processing and Analyzing Data}

The study used SPSS software to synthesize and analyze data. In the study, the following specific methods were used, including:

(1) Descriptive statistical method: This method is used to statistic the composition and characteristics of respondents: gender, school year, major, and other basic characteristics.

(2) Cronbach alpha reliability and exploratory factor analysis (EFA): This method is used to test the reliability of the scale and identify factors affecting student satisfaction with the facility service quality provided by FPT University Da Nang.

(3) A linear regression model: This model was established and analyzed to examine the effect of the factors on the dependent variable - student satisfaction with the facility service quality provided by FPT University Da Nang.

\section{Results}


Table 1. Demographic statistics $(\mathrm{N}=221)$

\begin{tabular}{|lcc|}
\hline \multicolumn{1}{|c}{ Variables } & Frequency & Percentage \\
Session & & \\
K13 (juniors) & 44 & $19.9 \%$ \\
K14 (seniors) & 109 & $49.3 \%$ \\
K15 (sophomores) & 68 & $30.8 \%$ \\
$\quad$ Genders & & \\
Male & 118 & $53.4 \%$ \\
Female & 103 & $46.6 \%$ \\
$\quad$ Major & & \\
International Business & 45 & $20.4 \%$ \\
Software Technology & 60 & $27.1 \%$ \\
Languages & 27 & $12.2 \%$ \\
Business Administration & 48 & $21.7 \%$ \\
Hotel Management & 12 & $5.4 \%$ \\
Graphic Design & 29 & $13.1 \%$ \\
\hline
\end{tabular}

Data collected from students using a structured questionnaire is via a previously discussed research model. Respondents for the study are students currently enrolled at FPT University Da Nang who have used the facilities provided by the school. This study was conducted using a set of questionnaires to 221 students by the convenient sampling method, excluding students from K16. Among the respondents, male respondents were 118 , thus representing $53.4 \%$ of the total population. Whereas the female respondents were 103 and thus presenting $44.6 \%$ of the total population. All the respondents are undergraduate students. The majority of the student population was between 19 to 22 years of age group.

(1) The results of scale quality testing:

Table 2. Scale quality results

\begin{tabular}{|c|c|c|c|}
\hline Variables & $\begin{array}{c}\text { Initially } \\
\text { observed } \\
\text { variable }\end{array}$ & $\begin{array}{c}\text { Observed } \\
\text { variables } \\
\text { remaining }\end{array}$ & $\begin{array}{c}\text { Cronbach's } \\
\text { Alpha }\end{array}$ \\
\hline Tangibles (TAN) & 5 & 4 & 0.833 \\
\hline $\begin{array}{c}\text { Responsiveness } \\
\text { (RES) }\end{array}$ & 3 & 3 & 0.769 \\
\hline Empathy (EMP) & 4 & 4 & 0.840 \\
\hline Assurance (ASS) & 3 & 3 & 0.747 \\
\hline Reliability (REL) & 3 & 3 & 0.640 \\
\hline Satisfaction (SAT) & 3 & 3 & 0.825 \\
\hline
\end{tabular}

The results showed that all factors have high Cronbach Alpha reliability coefficients, from $0.640-0.843$. These factors are greater than 0.6, which qualifies for EFA. Corrected Item-Total Correlation of the variables on the scale is greater than 0.3 except for the observed variable TAN4, so this observed variable is removed to meet the requirements and high reliability.

(2) The results of interpretation of the variables in the model:
Table 3. Rotated Component Matrix

\begin{tabular}{|c|c|c|c|c|c|}
\hline & \multicolumn{5}{|c|}{ Component } \\
\hline & 1 & 2 & 3 & 4 & 5 \\
\hline TAN2 & .866 & & & & \\
\hline TAN3 & .852 & & & & \\
\hline TAN1 & 699 & & & & \\
\hline TAN5 & .647 & & & & \\
\hline REL1 & & .856 & & & \\
\hline ASS2 & & .839 & & & \\
\hline ASS3 & & .838 & & & \\
\hline EMP1 & & & .758 & & \\
\hline EMP4 & & & .718 & & \\
\hline EMP2 & & & .654 & & \\
\hline EMP3 & & & .631 & & \\
\hline RES3 & & & & .774 & \\
\hline RES2 & & & & .714 & \\
\hline RES1 & & & & .648 & \\
\hline REL2 & & & & & .923 \\
\hline REL3 & & & & & .554 \\
\hline
\end{tabular}

From the rotation matrix result, the variable ASS1 has a load factor of less than 0.5 , so it doesn't load at any factor. Perform a second EFA factor analysis after eliminating 1 observed variable ASS1.

Results of the rotation factor matrix showed that the original 5 groups of factors were rearranged into 5 groups with different dimensions from the original.

- Factor 1: Includes 4 variables TAN3, TAN2, TAN1, TAN5, this group is named TAN (stand for Tangibles)

- Factor 2: Includes 3 variables from ASS3, REL1, ASS2, this group is named ASS (stand for Assurance) - Factor 3: Includes 4 variables EMP1, EMP4, EMP2, EMP3, this group is named EMP (stand for Empathy) - Factor 4: Includes 3 variables RES3, RES2, RES1, this group is named RES (stand for Responsiveness)

- Factor 5: Includes 2 variables REL2, REL3, this group is named REL (stand for Reliability)

Thus, can see from 18 initial variables (excluding 3 variables SAT1, SAT2, SAT3) and removing 2 low-reliability variables (TAN4, ASS1) to 16 observed variables, the results have been reorganized to 5 groups of variables represented. These are the 5 factors discovered that affect student satisfaction with the provision of facilities services to the FPT University students in Da Nang campus.

(3) The results of regression analysis:

The synthesis results show that the model with $\mathrm{R}^{2}=$ 0.709 (adjusted) shows that the independent variables in the model can explain $70.9 \%$ of the variation of the dependent variable, which means that $70.9 \%$ of student satisfaction FPT University with the school facilities 
services quality is explained by 5 variables discovered in this study. The remaining $29.1 \%$ is due to the non-model variables and random error. Besides, the value of Durbin Warson $=1.547$ is in the range of $1.5-2.5$, so there is no correlation between the residues. The model does not violate assumptions about the independence of the error.

Table 4. Model summary

\begin{tabular}{|c|c|c|c|c|c|}
\hline Model & $\mathrm{R}$ & $\begin{array}{c}\mathrm{R} \\
\text { Square }\end{array}$ & $\begin{array}{c}\text { Adjusted R } \\
\text { Square }\end{array}$ & $\begin{array}{c}\text { Std. Error of } \\
\text { the Estimate }\end{array}$ & $\begin{array}{c}\text { Durbin- } \\
\text { Watson }\end{array}$ \\
\hline 1 & $.846^{\mathrm{a}}$ & .716 & .709 & .45216 & 1.547 \\
\hline
\end{tabular}

a. Predictors: (Constant), REL, TAN, ASS, RES, EMP

b. Dependent Variable: SAT

This study uses a linear regression model to examine the relationship between the 5 factors drawn from the above EFA analysis. In this study, the linear regression model is rewritten as follows:

$$
\begin{gathered}
\mathrm{SAT}=\beta 1 * \mathrm{TAN}+\beta 2 * \mathrm{ASS}+\beta 3 * \mathrm{EMP}+\beta 4 * \mathrm{RES}+ \\
\beta 5^{*} \mathrm{REL}
\end{gathered}
$$

In which: SAT: dependent variable

TAN, ASS, EMP, RES, REL: independent variables

$\mathrm{Bi}$ : standardized coefficient for each variable

The regression results are given in the following table 5.

The results of the analysis of the regression coefficients in the model showed that the significance of the TAN, ASS, EMP, and REL have Sig. <0.05, except for RES with Sig. = $0.391>0.05$. Therefore, the independent variables have an effect on student satisfaction except that the RES variable does not affect student satisfaction. The TAN, ASS, EMP, and REL components all have meaning in the model and have a positive impact on student satisfaction because the regression coefficients of those components all have a positive sign. Based on the magnitude of the standardized regression coefficient beta, the order of the level of impact from strongest to weakest of the independent variables to the dependent variable SAT is REL (0.309)> TAN (0.288)> $\operatorname{EMP}(0.243)>\operatorname{ASS}(0.172)$.

The VIF coefficient of the independent variables TAN and EMP is greater than 2, so there is a phenomenon of multicollinearity. This phenomenon is explained that in our study, there exists a high correlation between these two independent variables in the regression model. In other words, an independent variable can be used to predict another. When the independent variable EMP donates, the independent variable TAN increases and vice versa, the EMP decreases, the TAN also decreases.

From the regression results, the regression function is rewritten as follows:

$$
\begin{gathered}
\mathrm{SAT}=0.288 * \mathrm{TAN}+0.172 * \mathrm{ASS}+0.243 * \mathrm{EMP}+ \\
0.309 * \mathrm{REL}
\end{gathered}
$$

\section{Explanation of model meaning:}

1. Tangibles (TAN) variable has a coefficient of 0.288 , which indicates that the addition of one more assessment point will make students satisfied with the conditions of facilities served by FPT University Da Nang increased to 0.288 points;

2. The assurance (ASS) variable has a coefficient of 0.172 , which indicates that an increase of one point in the assessment of the assurance degree of students' requirements will result in student satisfaction with the facilities being served by FPT University Da Nang increased to 0.172 points;

3. The empathy (EMP) variable has a coefficient of 0.243 , which indicates that an increase of one point in an assessment score of the school's empathy level will result in student satisfaction with the facilities served by the FPT University Da Nang increased to 0.243 points. This independent variable has a multicollinearity phenomenon with the independent variable (TAN). This means that when the school empathizes with students' requests, the school will always actively improve its facilities (TAN). On the contrary, if empathy doesn't exist, the university cannot understand the needs of students to satisfy them. These two independent variables cause the regression test to be significantly limited;

4. The reliability (REL) variable has a coefficient is 0.309 , which indicates that the addition of one more assessment point will make students satisfied with the conditions of facilities served by FPT University Da Nang increased to 0.309 points.

Table 5. Coefficients

\begin{tabular}{|c|c|c|c|c|c|c|c|}
\hline \multirow{2}{*}{ Model } & \multicolumn{2}{|c|}{ Unstandardized Coefficients } & Standardized Coefficients & \multirow{2}{*}{ t } & \multirow{2}{*}{ Sig. } & \multicolumn{2}{|c|}{ Collinearity Statistics } \\
\cline { 2 - 4 } & $\mathbf{B}$ & Std. Error & Beta & & & Tolerance & VIF \\
\hline (Constant) & -.191 & .187 & & -1.025 & .306 & & \\
\hline TAN & .269 & .052 & .288 & 5.165 & .000 & .424 & 2.360 \\
\hline ASS & .164 & .046 & .172 & 3.537 & .000 & .558 & 1.792 \\
\hline EMP & .225 & .052 & .243 & 4.336 & .000 & .420 & 2.379 \\
\hline RES & .046 & .054 & .044 & .859 & .391 & .512 & 1.953 \\
\hline REL & .333 & .046 & .309 & 7.188 & .000 & .713 & 1.402 \\
\hline
\end{tabular}




\section{Discussion}

The research is based on the theory of service quality bringing customer satisfaction, thereby synthesizing relevant practical studies to build a model to evaluate student satisfaction at private universities. The sustainable development of a university is influenced by many factors, of which student satisfaction is one of the most important. The research is analyzed based on the service quality research model including 5 main factors: tangible, responsiveness, empathy, assurance, and reliability.

According to the results, responsiveness is a factor that does not have a significant impact on the satisfaction of students with the school's facilities. In addition, the regression results also clearly determined that the reliability variable had the most crucial impact on student satisfaction. Most students assess that the institute's commitments to providing facilities are guaranteed. Problems and inquiries about facility service quality are provided promptly. It can be understood that most of the students expect a school with modern and convenient amenities to meet their learning and living needs. All students require the institution to provide a broad range of services as well as facilities according to what they introduced before students enter this school. Therefore, the satisfaction of what is committed to customers is considered as the leading factor that private schools need to ensure.

Tangibles is the second influential variable, ranked after reliability. This can be explained when FPT University is at the top of private universities with modern amenities commensurate with the tuition fees students are willing to promptly pay in Vietnam. FPT University at Da Nang campus has met the needs of facilities for students, not only learning equipment, but the school also has provided some facilities to support physical health such as soccer field, basketball court, athletic facility. In addition, the library also provides free materials according to the foreign curriculum for each student's course. However, one of the recent complaints from students at FPT Da Nang University efficiently is their considerable dissatisfaction with the parking lot of the school. It may be just an insignificant factor, but it can affect the student's experience at school in the long run. Therefore, not only FPT University but also other universities should thoroughly understand each student's demands to fully satisfy and increase their satisfaction with the quality of the university. Besides, academic institutions need to regularly renew and improve the excellent quality of their facilities to remain progressively modern, keeping up with the global trend of educational service quality. Meet the needs of domestic and international students at private universities.

Accordingly, the dedication, enthusiasm, or is adequately understood as the assurance of the facility staff in the process of providing services of private educational institutions to students, as well as the reputation of the school to merely ensure equipment always supports students is factors that need to be paid more attention. Employees act as a key bridge between service delivery and the perception of customer satisfaction. This not only makes an image but also builds a lasting satisfaction for private universities. Even the service staff such as cleaning and private security guards also need to carefully help and enthusiastically support students in adapting and performing activities on campus. In essential particular, the private school must always listen to the accurate assessment and specific feedback about the necessary provision of suitable facilities for student learning and social activities.

Finally, empathy equally determines in part the student's satisfaction at private schools about the quality of the facilities served. Student requirements for testing and comprehensive evaluation, thereby improving service quality are always necessary. From getting prompt comments and constructive feedback, academic institutions can quickly spot gaps and fill them with student satisfaction. In addition, the school also needs to create conditions for all students to participate in community activities to improve students' practical skills. Properly providing considerable interest to prospective students is key to generating a positive experience for the educational institution's own clients.

According to the above important findings of the study, discussions will be reviewed its significance and support by previous studies. The research results initially clarify the positive trend of each selected variable for the study. To be specific, the results highlighted the student's satisfaction with the school's reliability $(\beta 4=0.309)$ in the quality of service facilities, followed by tangibility $(\beta 1=0.288)$, empathy $(\beta 3=0.243)$, and assurance $(\beta 2=0.172)$. Meanwhile, the responsiveness factor is considered not affecting student satisfaction in the author's study. Besides, the relationship between overall service quality and student satisfaction of 0.709 means this relationship is stronger than average. Seeing that reliability and tangibility had a stronger relationship than empathy and assurance prompted the researcher back to what Chua [12] had emphasized, taking it as a compliment with services offered in private higher education to increase satisfaction. Tran (2006), in his research, mentioned that assurance was one of the most significantly related aspects of satisfaction followed by reliability. It is found that, although aspects of service quality are critical, responsiveness is considered one of the most important factors Nguyen (2010). Consistent with what Snipes and Thomson (1999) describe in their research, say that although all aspects of service quality help explain student satisfaction but that doesn't mean all aspects are meaningful. Unlike public schools, it is evident a private school is committed to influencing the most students, as a strategy for engaging their clients. The cost of public educational institutions is sponsored by the 
government, and the fees students pay are considered satisfied with what they receive. In that case, the tangible elements obtain the means provided to support the teaching and learning process, the evidence to bring empathy and assurance for students throughout the experience. Therefore, students in private schools expect more from other factors but overlook responsiveness factors when assessing their level of satisfaction at private schools.

\section{Conclusion}

The research is based on the theory of service quality to provide customer satisfaction, thereby synthesizing relevant practical studies to build a model of student satisfaction assessment of the private universities. The sustainable development of a university is influenced by many factors, of which student satisfaction is one of the most important factors. The school must always innovate and improve student satisfaction, not only about the facilities of the school, but also the quality of the teaching and the qualifications of the faculty. Besides, the school also needs to create conditions for all students to participate in community activities to improve students' practical skills.

This study has applied the service quality model SERVQUAL which is a well-known method of Parasuraman for measuring the quality of service through processing customer satisfaction. SERVQUAL model includes 5 components: (1) Reliability, (2) Responsiveness, (3) Tangibles, (4) Assurance, and (5) Empathy. Survey results from 221 students assessed the current state of the facilities provided, indicating the factors affecting student satisfaction with the quality of services that the school meets. Specifically, 4 main groups of factors that affect student satisfaction at private universities include (1) Tangible, (2) Assurance, (3) Empathy, and (4) Reliability. The research results have helped to provide suggestions and important foundations in building solutions to improve the quality of services provided and improve student satisfaction at private universities. By measuring the satisfaction of students with certain service elements to recognize the service quality, it detects the weaknesses and limitations in service delivery, as a basis for improving and enhancing service quality.

Although qualitative factors have been quantified scientifically and evidently, there are also a few limitations. Firstly, this study examines the 4 components of educational service quality to student satisfaction, and it explains $70.9 \%$ of the variation in student satisfaction. Thus, several other factors can affect student satisfaction besides the proposed research model. Secondly, this research was conducted in the situation of the COVID-19 pandemic, it is necessary to conduct further research in a normal period. In addition, the future research direction, proposing solutions to improve service quality, needs time to prepare and to check samples collected from questionnaires satisfactorily. The content describes the cause or reason for satisfaction, combined with factor analysis to clarify the basis and propose solutions.

\section{Conflict of Interest}

The authors declare no conflicts of interest. The authors also declare that they have no known competing financial interests or personal relationships that could have appeared to influence the work reported in this paper. 


\section{APPENDIX}

Table 6. Questionnaire items

\begin{tabular}{|c|c|c|c|c|c|c|}
\hline ORDER & VARIABLES & \multirow{2}{*}{1} & \multirow{2}{*}{2} & \multirow{2}{*}{3} & \multirow{2}{*}{4} & \multirow{2}{*}{5} \\
\hline I & Tangibles (TAN) & & & & & \\
\hline TAN1 & $\begin{array}{l}\text { The number of classrooms is guaranteed, clean, well-lit, well-ventilated, and fully } \\
\text { equipped. }\end{array}$ & & & & & \\
\hline TAN2 & $\begin{array}{l}\text { The school library has abundant study materials and references, convenient search } \\
\text { facilities. }\end{array}$ & & & & & \\
\hline TAN3 & $\begin{array}{l}\text { Dormitory, gymnasium, leisure spot, campus for students with enough, clean, } \\
\text { suitable equipment }\end{array}$ & & & & & \\
\hline TAN4 & The electricity and water system are fully provided and convenient. & & & & & \\
\hline TAN5 & $\begin{array}{l}\text { The University's information system and website are regularly updated and easy to } \\
\text { access. }\end{array}$ & & & & & \\
\hline II & \multicolumn{6}{|l|}{ Responsiveness (RES) } \\
\hline RES1 & The management staff is capable of working, managing, and serving well. & & & & & \\
\hline RES2 & The school regularly organizes the repair and maintenance of facilities. & & & & & \\
\hline RES3 & $\begin{array}{l}\text { The school has complete, convenient, and easy-to-search information and } \\
\text { instruction charts. }\end{array}$ & & & & & \\
\hline III & \multicolumn{6}{|l|}{ Empathy (EMP) } \\
\hline EMP1 & $\begin{array}{l}\text { The school regularly organizes to collect students' opinions on the quality } \\
\text { assessment of living and learning conditions. }\end{array}$ & & & & & \\
\hline EMP2 & $\begin{array}{l}\text { The school regularly checks and evaluates the quality of facilities serving students' } \\
\text { learning and activities. }\end{array}$ & & & & & \\
\hline EMP3 & $\begin{array}{l}\text { The school regularly renovates and modernizes facilities for the living and } \\
\text { studying of students. }\end{array}$ & & & & & \\
\hline EMP4 & $\begin{array}{l}\text { Students' questions and feedback are listened to, responded to, and handled quickly } \\
\text { and properly by the University. }\end{array}$ & & & & & \\
\hline IV & \multicolumn{6}{|l|}{ Assurance (ASS) } \\
\hline ASS1 & $\begin{array}{l}\text { The service staff has a working spirit, is considerate, ready to guide and answer } \\
\text { students' questions. }\end{array}$ & & & & & \\
\hline ASS2 & The service staff always do their job right. & & & & & \\
\hline ASS3 & $\begin{array}{l}\text { The number of services arranged reasonably, fully, and convenient to answer } \\
\text { questions of students. }\end{array}$ & & & & & \\
\hline $\mathrm{V}$ & \multicolumn{6}{|l|}{ Reliability (REL) } \\
\hline REL1 & $\begin{array}{l}\text { Information related to learning and activities is provided to students fully and } \\
\text { promptly. }\end{array}$ & & & & & \\
\hline REL2 & The time to answer and answer questions of students is done on time and quickly. & & & & & \\
\hline REL3 & The facilities were provided exactly as committed. & & & & & \\
\hline VI & \multicolumn{6}{|l|}{ Satisfaction (SAT) } \\
\hline SAT1 & Students are satisfied with the facilities of the University. & & & & & \\
\hline SAT2 & Students are satisfied with the school's service attitude. & & & & & \\
\hline SAT3 & Students are satisfied with the commitments and efforts of the University. & & & & & \\
\hline
\end{tabular}

[3] Selvanathan, M., Yan, D., Supramaniam, M., Arumugam, T. and Suppramaniam, S. Lecturers' Productivity in Private Universities, Kazakhstan. Universal Journal of Educational Research, 7(12), pp.2558-2567, 2019

\section{REFERENCES}

[1] R. Karaim. Expanding higher education, CQ Global Researcher, 5, 525-572, 2011. Online available from http://library.cqpress.com/

[2] H. F. A. Hasan, A. Ilias, R. A. Rahman, M. Z. A. Razak. Service quality and student satisfaction: A case study at private higher education institutions, International Business Research, 1.3: 163-175, 2008.

[4] FPT University, Awards and achievements. Online available from http://international.fpt.edu.vn/fpt-university -the-only-vietnamese-academic-institution-attained-5-stars -level-for-employability-rate/ (accessed Feb. 16, 2021)

[5] FPT, FPT Education wins two Brand Laureate awards. Online available fromhttps://fpt.com.vn/en/newsroom/deta il/fpt-education-wins-two-brandlaureate-awards (accessed Feb. 16, 2021) 
[6] FPT Education, FPT University introduces new campus project in Da Nang. Retrieved 09 Feb, 2021 from http://int ernational.fpt.edu.vn.

[7] C. W. Chuah, S. S. Ramalu. Students satisfaction towards the university: Does service quality matters? International Journal of Education, 3.2: 1-15, 2011.

[8] Y. Yi. A critical review of consumer satisfaction. Review of marketing, 4.1: 68-123, 1990.

[9] H. Lee, Y. Lee, D. Yoo. The determinants of perceived service quality and its relationship with satisfaction. Journal of services marketing, 2000.

[10] J. J. Cronin Jr, M. K. Brady, G. T. M. Hult. Assessing the effects of quality, value, and customer satisfaction on consumer behavioral intentions in service environments. Journal of retailing, 76.2: 193-218. 2000.

[11] R. L. Snipes, N. Thomson. An empirical study of the factors underlying student service quality perceptions in higher education. Academy of Educational Leadership Journal, 3.1: 39-57, 1999.

[12] C. Chua. Perception of quality in higher education. In Proceedings of the Australian universities quality forum (pp. 1-7). Melbourne: AUQA Occasional Publication, 2004 July.

[13] X. K. Tran. Evaluate the student's satisfaction with the training quality at Thai Nguyen University of Economics and Business Administration. Education Management Master Thesis. Institute of Education Quality Assurance, Hanoi National University, 2006.

[14] T. T. Nguyen. Surveying student satisfaction with training activities at University of Science, National University of Ho Chi Minh City: Thesis MSc. Measurement and Evaluation in Education. PhD Thesis. Education Quality Assurance Institute, 2010

[15] Parasuraman, V. A. Zeithaml, L. L. Berry. A conceptual model of service quality and its implications for future research. Journal of marketing, 49.4: 41-50, 1985.

[16] F. Buttle. SERVQUAL: review, critique, research agenda. European Journal of Marketing, 1996.

[17] J. Wirtz, C. Lovelock. Essentials of Service Marketing 3rd edition. Pearson. Part 1, chapter 2, pp. 55-57, 2018.

[18] H. A. Tran. Application of structural equation modeling to examine the relationship between educational quality and student feeling of satisfaction: a case study of the Faculty of
Economic at VHU, 2016. Van Hien University Journal of Science.

[19] J. Haywood - Farmer. A conceptual model of service quality. International journal of operations \& production management, 1988.

[20] M. S. Sohail, N. M. Shaikh. Quest for excellence in business education: a study of student impressions of service quality. International Journal of Educational Management, 2004.

[21] M. Pakurár, H. Haddad, J. Nagy, J. Popp, J. Oláh. The service quality dimensions that affect customer satisfaction in the Jordanian banking sector. Sustainability, 11.4: 1113, 2019.

[22] Hardiyansyah. Quality of Public Services: Concept, Dimensions, Indicators and Implementation. Yogyakarta, Indonesia: Gava Media, 2011.

[23] T. S. Maesaroh. Relationship of service quality dimensions with service satisfaction antenatal care. Journal of Applied Health Management and Technology, 2.4: 128-136, 2020.

[24] Y. C. Hou. Mutual recognition of quality assurance decisions on higher education institutions in three regions: A lesson for Asia. Higher Education, 64.6: 911-926, 2012.

[25] E. M. Varonis. Most courses are not born digital: An overview of the Quality Matters peer review process for online course design. Campus-Wide Information Systems, 31.4: 217-229, 2014.

[26] T. Ryan. Quality assurance in higher education: A review of literature, 2015.

[27] Parasuraman, V. A. Zeithaml, L. L. Berry. Reassessment of expectations as a comparison standard in measuring service quality: implications for further research. Journal of marketing, 58.1: 111-124, 1994.

[28] T. Singer, C. Lamm. The social neuroscience of empathy. Annals of the New York Academy of Sciences, 1156.1: 81-96, 2009.

[29] S. L. Vargo, R. F. Lusch. Evolving to a new dominant logic for marketing. Journal of marketing, 68.1: 1-17, 2004.

[30] H. T. Tan, B. Muskat, R. Johns. The role of empathy in the service experience. Journal of Service Theory and Practice, 2019.

[31] J. F. Hair, W. C. Black, B. J. Babin, R. E. Anderson, \& R. Tatham. Multivariate data analysis. Uppersaddle River, 2006. 